EDITORIAL

\title{
Wabah COVID-19 Tahun 2021
}

\author{
Patrianef Darwis ${ }^{1}$ \\ ${ }^{1}$ Divisi Bedah Vaskular dan Endovaskular, Departemen Ilmu Bedah Fakultas Kedokteran Universitas \\ Indonesia/ Rumah Sakit Cipto Mangunkusumo
}

Assalamualaikum wr wb.

Sejawat sekalian, tahun 2021 berada di depan mata kita dan tahun 2020 sudah hampir meninggalkan kita. Sangat banyak duka dan kesedihan kita selama menjalani tahun 2020 ini. Penyebab dari banyak kesusahan itu adalah wabah COVID-19.

Di tahun 2020 ini, semua sektor kehidupan terkena dampak oleh tersebarnya wabah COVID-19 di seluruh dunia, tidak terkecuali Indonesia. Sebagai bagian masyarakat global yang nyaris tidak punya sekat dan batas maka dampak dari wabah ini menyebar ke seluruh pelosok dunia, bahkan tempat yang terpencil sekalipun. Sepanjang ada transportasi dan mobilitas orang ke wilayah tersebut maka penyebaran COVID-19 di tempat tersebut tidak bisa dihindari.

Kita sebagai spesialis bedah juga terkena dampak dalam berinteraksi dengan pasien yang biasanya selama ini tanpa sekat, saat ini kita membangun sekat dan penghalang dalam berkontak dan berinteraksi dengan pasien. Sekat dan penghalang yang kita bangun berfungsi melindungi pasien dan diri kita tertular dan menularkan wabah COVID-19 selama proses interaksi berlangsung. Selain itu, jika pasien terkonfirmasi positif COVID-19 maka sekat dan penghalang yang dinamakan Alat Pelindung Diri tersebut semakin lengkap dan kompleks. Sungguh ini suatu hal yang tidak nyaman baik bagi pasien maupun bagi diri kita sendiri.

Selain dampak sosial, dampak ekonomi juga dirasakan oleh seluruh elemen masyarakat termasuk dunia kedokteran. Pembayaran jasa dokter yang dihitung berdasarkan volume kerja juga terkena dampak karena tindakan dan operasi elektif dibatasi selama masa pandemi ini, dan jika pun itu dilaksanakan dengan pembatasan dan syarat ketat yang pada akhirnya dibebankan pada pasien. Hal minimal yang harus dilakukan oleh pasien adalah pembiayaan pemeriksaan RT-PCR dari swab tenggorokan. Selain dampak sosial, risiko kematian berada di depan seorang dokter saat menangani pasien, 


\section{EDITORIAL}

sehingga banyak dokter dan tenaga kesehatan yang menderita COVID-19 bahkan meninggal akibat COVID-19.

Kejadian wabah yang berdampak berat baik secara sosial, ekonomi maupun psikologi juga membuat kita lebih kuat dan tangguh dalam menghadapi tantangan dimasa depan. Kita berharap bahwa kita akan semakin kuat ditahun depan.

Kita di Indonesia juga harus mencermati bahwa kecenderungan globalis yang selama ini terjadi akan berubah menjadi lokalis, dampak yang lebih sederhana misalnya pasien yang selama ini berobat keluar negeri akan jauh berkurang karena pembatasan mobilitas orang antar wilayah dan negara. Bagaimanapun, kecenderungan lokalis ini akan berlanjut di tahun 2021, karena kita tidak akan tahu pasti kapan ujung dari wabah COVID-19 ini.

Kita berharap wabah ini segera berakhir dan kita dapat kembali melanjutkan kehidupan dan berinteraksi dengan cara yang biasa dan wajar kembali. Harapan yang jelas ada di tahun depan adalah dengan dimulainya pemberian vaksin COVID-19 pada masyarakat dan tenaga kesehatan. Semoga tahun depan akan lebih baik dibandingkan tahun 2020 .

Kami berharap agar semua anggota IKABI tetap menjaga kesehatan dengan cara menjaga jarak dan sering mencuci tangan dalam berinteraksi dengan lingkungan sekitarnya. Salam sehat untuk kita semua.

Korespondensi Penulis:

Patrianef Darwis

Divisi Bedah Vaskular dan Endovaskular.

Departemen Ilmu Bedah Fakultas Kedokteran

Universitas Indonesia

Rumah Sakit Cipto Mangunkusumo

email : patrianef@gmail.com

ORCID ID

https://orcid.org/0000-0002-4982-9034 